19 (4): 357 - $362(2020)$

(ㅇ / ISSN 07177917 / www.blacpma.ms-editions.cl

\title{
Artículo Original | Original Article Cytotoxic activity of crude extracts and fractions from Blepharocalyx cruckshanksii against selected human cancer cell lines
}

\author{
[Actividad citotóxica de extractos crudos y fracciones de Blepharocalyx cruckshanksii contra líneas celulares de \\ cáncer humano seleccionadas]
}

\author{
Carolina Baez ${ }^{1}$, Joan Villena², Iván Montenegro ${ }^{3}$, Alessandra Russo ${ }^{4}$, Bastian Said ${ }^{5}$ \& Alejandro Madrid ${ }^{1}$ \\ ${ }^{1}$ Laboratorio de Productos Naturales y Síntesis Orgánica (LPNSO), Departamento de Química, Facultad de Ciencias Naturales y \\ Exactas, Universidad de Playa Ancha, Valparaíso, Chile \\ ${ }^{2}$ Centro de Investigaciones Biomedicas, Facultad de Medicina, Campus de la Salud, Universidad de Valparaíso, Viña del Mar, Chile \\ ${ }^{3}$ Escuela de Obstetricia y Puericultura, Facultad de Medicina, Universidad de Valparaíso, Viña del Mar, Chile \\ ${ }^{4}$ Department of Drug Sciences, University of Catania, Catania, Italy \\ ${ }^{5}$ Departamento de Química, Universidad Técnica Federico Santa María, Santiago, Chile \\ Contactos | Contacts: Alejandro MADRID - E-mail address: alejandro.madrid@upla.cl
}

\begin{abstract}
The present study aims to explore the potential applications of Blepharocalyx cruckshanksii bark and leaf extracts as a cytotoxic agent against in vitro cancer cell lines (MCF-7, PC-3 and HT-29) by using sulforhodamine B (SRB) assay. The cytotoxicity assay revealed that the ethyl acetate extract from the bark exhibited marked anticancer activity. The active extract was subjected to liquid-liquid partitioning by using hexane and ethyl acetate to obtain fractions based on their polarity. However, Fraction 4 (F4) was identified as the most effective of the series by displaying against all cancer cell lines a cytotoxicity close to antineoplastic agents assayed. Then, F4 was analyzed by gas chromatography-mass spectrometry (GC-MS) to identify their major components and to relate these components to the cytotoxic effect. The results obtained indicated that B. cruckshanksii bark have excellent cytotoxic activity and warrant further studies to isolate novel compounds for chemotherapeutic use.
\end{abstract}

Keywords: Blepharocalyx cruckshanksii; Bark; Cancer cell; Gas chromatography

Resumen: El presente estudio tiene como objetivo explorar las posibles aplicaciones de los extractos de corteza y hoja de Blepharocalyx cruckshanksii como agente citotóxico contra líneas celulares de cáncer in vitro ((MCF-7, PC-3 y HT-29) mediante el uso de ensayo de sulforhodamine B (SRB). El ensayo de citotoxicidad reveló que el extracto de acetato de etilo de la corteza exhibía una actividad anticancerígena marcada. El extracto activo se sometió a un reparto líquido-líquido usando hexano y acetato de etilo para obtener fracciones basadas en su polaridad. Sin embargo, la Fracción 4 (F4) fue identificado como el más efectivo de la serie al mostrar contra todas las líneas celulares de cáncer una citotoxicidad cercana a los agentes antineoplásicos ensayados. Luego, F4 se analizó por cromatografía de gasesespectrometría de masas (GC-MS) para identificar sus componentes principales y relacionar estos componentes con el efecto citotóxico. Los resultados obtenidos indicaron que la corteza de B. cruckshanksii tiene una excelente actividad citotóxica y amerita estudios adicionales para aislar nuevos compuestos para quimioterapia.

Palabras clave: Blepharocalyx cruckshanksii; Corteza; Celulas de cáncer; Cromatografía de gases

Recibido | Received: January 3, 2020

Aceptado| Accepted: February 14, 2020

Aceptado en versión corregida | Accepted in revised form: March 2, 2020

Publicado en línea | Published online: July 30, 2020

Este artículo puede ser citado como / This article must be cited as: C Baez, J Villena, I Montenegro, A Russo, B Said, A Madrid. 2020 Cytotoxic activity of crude extracts and fractions from Blepharocalyx cruckshanksii against selected human cancer cell lines. Bol Latinoam Caribe Plant Med Aromat 19 (4): 357 - 362.

https://doi.org/10.37360/blacpma.20.19.4.23 


\section{INTRODUCTION}

Cancer is one of the most persistent health problems and is considered as a major threat to humankind (Tantengco \& Jacinto, 2015). According to the World Health Organization, cancer is the second leading cause of death globally, and is responsible for an estimated 9.6 million deaths in 2018. Globally, about 1 in 6 deaths is due to cancer (WHO, 2019). Nowadays, chemotherapy is the main treatment with drugs that can destroy cancer cells, however, the drawback of these anticancer drugs is presented as they are highly toxic with low treatment effectiveness and significant reduction in the quality of life of the cancer patients (Nguyen \& Scarlett, 2019). Currently, there is a considerable scientific and commercial interest in continuing the discovery of new anticancer agents from natural products with the strategy of chemotherapy protocols being killing the cancer cells with no toxic effect on the host (Elufioye et al., 2017). Natural products are well recognized as source of cytotoxic molecules while several others can decrease the resistance of cancer cells to chemotherapeutic drugs, improve the efficiency of chemotherapeutic agents, and reduce the adverse side effects experienced due to chemotherapy (Elufioye $e t$ al., 2017; Mbaveng et al., 2019). However, the genus Blepharocalyx have been explored for various activities based on traditional uses. The active metabolites isolated from Blepharocalyx salicifolius (Kunth) O. Berg showed anti-cancer potential (Siqueira et al., 2011). In other study the essential oil of $B$. salicifolius showed significant activity against breast cancer cell line MDA-MB-231 (46.60 $\mu \mathrm{g} / \mathrm{mL})$ and revealed to have induced cell death through apoptosis (Furtado et al., 2018).

Blepharocalyx cruckshanksii (Hook. \& Arn.) Nied. is native to the Chile and is locally known as temu. Leaves of $B$. cruckshanksii are used as astringent and vulnerary (Gusinde, 1936). Water decoction of its bark is used to treat diarrhea (Massardo \& Rozzi, 1996). Compounds isolated from bioactive fractions of $B$. cruckshanksii were observed to have antimycobacterial activity (Massardo \& Rozzi, 1996). Other ethnomedicinal uses of $B$. cruckshanksii are remedies for rheumatism and wounds (Gusinde, 1936; Massardo \& Rozzi, 1996).

Therefore, the present study was carried out to explore the anticancer activity of extracts and fractions from $B$. cruckshanksii bark and leaves on a panel of three human cancer cell lines: MCF-7 (breast), PC-3 (prostate) and HT-29 (colon), and two human non-tumoral cell lines, HDF (Human dermal fibroblasts) and $\mathrm{CoN}$ (colon epithelial).

\section{MATERIALS AND METHODS Plant Material}

Leaves and bark of B. cruckshanksii were collected in the locality Laguna Verde, Valparaíso, Chile $\left(33^{\circ} 03^{\prime} 04^{\prime \prime} \mathrm{S}, 71^{\circ} 39^{\prime} 34^{\prime \prime} \mathrm{O}\right)$, in the morning (10 am) of October 17, 2018. A voucher specimen was deposited in the Natural Products Laboratory, University of Playa Ancha (Valparaíso, Chile), under the BC2018-17.10. The identity of the species was validated by Patricio Novoa, Forestal engineer and expert in botany.

\section{Extraction of crude extracts}

The bark $(1.00 \mathrm{Kg})$ and leaves $(1.00 \mathrm{~kg})$ were air dried at room temperature after collection. The dried samples were crushed by using a blender. Dried and crushed samples were subjected to successive extractions using different solvents of increasing polarity (n-hexane, dichloromethane, ethyl acetate and ethanol) like a procedure reported in a previous study (Mellado et al., 2019). All the obtained extracts were concentrated in a rotary evaporator at $40{ }^{\circ} \mathrm{C}$, and then each extract was stored at room temperature in the dark.

\section{Fractionation of active extract}

The bark ethyl acetate extract $(4.00$ g) was fractionated by column chromatography on silica gel using n-hexane-ethyl acetate (100:0 to $0: 100, \mathrm{v} / \mathrm{v})$ to obtain one hundred and fifty fractions of $50 \mathrm{~mL}$ each were collected and combined on the basis of their thin layer chromatography (TLC) profiles to afford seven main fractions. Fractions 1-22, 23-45, 46-66, 67-90, 91-118, 119-138, and 139-150 were referred to as F1, F2, F3, F4, F5, F6 and F7 respectively. These fractions were tested for their cytotoxicity activity and the most active fraction was subjected to gas chromatography-mass spectrometry (GC-MS) in order to identify the active principles.

\section{Identification of active fraction}

F4 was diluted with ethyl acetate, and analysis was performed by GC/MS using the instrumentation described elsewhere (Canales et al., 2016). 
Cell Viability Assay

The sulforhodamine B assay was assessed by the procedure previously described in reference (Madrid et al., 2011). Daunorubicin and dunnione were used as positive controls. Results were analyzed using MS Excel and Sigmaplot 12.5 software.

\section{Statistical analysis}

Determinations of $\mathrm{IC}_{50}$ were performed in triplicate and the results are expressed as mean values \pm SD. The results were analyzed by the standard method (Madrid et al., 2011).

\section{RESULTS AND DISCUSSION \\ Yield of crude extracts}

The yield of the crude n-hexane (Hex), dichloromethane (DCM), ethyl acetate (EtOAc) and ethanol (EtOH) extracts from leaves and bark of $B$. cruckshanksii are summarized in Table No. 1.

Table No. 1

Extraction yield of crude extracts

\begin{tabular}{ccccc} 
& Hex & DCM & EtOAc & EtOH \\
\cline { 2 - 5 } & \multicolumn{4}{c}{ Yield $(\%$ w/w) } \\
\hline Leaves & 1.51 & 1.33 & 6.04 & 4.7 \\
Bark & 1.17 & 1.03 & 1.50 & 1.32 \\
\hline
\end{tabular}

The highest yields were achieved with ethanol $12.62 \%(\mathrm{w} / \mathrm{w})$, followed by hexane $5.49 \%$ (w/w), and dichloromethane $4.76 \%(\mathrm{w} / \mathrm{w})$, while the lowest was ethyl acetate $3.55 \%(\mathrm{w} / \mathrm{w})$.
Chemical Composition of F4 from bark AcOEt extract

Results of the gas chromatographic analysis of F4 from bark ethyl acetate extract of B. cruckshanksii are summarized in Table No. 2.

Table No. 2

Main components of $F 4$

\begin{tabular}{|c|c|c|c|c|c|}
\hline No. & Main Components & $\%$ Area $^{a}$ & $\mathbf{R I}^{\mathbf{b}}$ & RIref $^{c}$ & Identification \\
\hline 1 & $\alpha$-pinene & 0.67 & 941 & 941 & RI, MS \\
\hline 2 & camphene & 0.81 & 953 & 952 & RI, MS \\
\hline 3 & 1-octen-3-ol & 0.57 & 979 & 978 & RI, MS \\
\hline 4 & $\beta$-pinene & 0.84 & 985 & 985 & RI, MS \\
\hline 5 & myrcene & 0.91 & 994 & 994 & RI, MS \\
\hline 6 & limonene & 2.01 & 1038 & 1039 & RI, MS \\
\hline 7 & $E$ - $\beta$-ocimene & 0.34 & 1049 & 1050 & RI, MS \\
\hline 8 & methyl eugenol & 4.85 & 1400 & 1401 & RI, MS \\
\hline 9 & aromadendrene & 29.05 & 1439 & 1439 & RI, MS \\
\hline 10 & cis-calamenene & 1.35 & 1531 & 1531 & RI, MS \\
\hline 11 & Caryophyllene oxide & 0.33 & 1581 & 1581 & RI, MS \\
\hline 12 & syringaldehyde & 9.93 & 1655 & 1656 & RI, MS, Co-I \\
\hline 13 & Patchouli alcohol & 3.28 & 1632 & 1663 & RI, MS, Co-I \\
\hline 14 & Loliolide & 2.36 & 1698 & 1698 & RI, MS \\
\hline 15 & neophytadiene & 0.68 & 1837 & 1839 & RI, MS \\
\hline 16 & curcumenone & 5.45 & 1845 & 1844 & RI, MS \\
\hline 17 & cyclopentadecanol & 0.57 & 1987 & 1988 & RI, MS \\
\hline 18 & hexacosane & 1.58 & 2600 & 2600 & RI, MS \\
\hline 19 & octacosane & 0.72 & 2800 & 2800 & RI, MS \\
\hline 20 & nonacosane & 1.09 & 2900 & 2900 & RI, MS \\
\hline 21 & quercetin & 6.55 & 3174 & 3176 & RI, MS, Co-I \\
\hline
\end{tabular}

Boletín Latinoamericano y del Caribe de Plantas Medicinales y Aromáticas/359 
Twenty-one components were identified, representing $73.94 \%$ of the total $\mathrm{F} 4$ and $26.06 \%$ were unknown compounds. The F4 was mainly characterized by aromadendrene (29.05\%), syringaldehyde (9.93\%), quercetin (6.55\%), curcumenone $(5.45 \%)$, methyl eugenol $(4.85 \%)$, and Patchouli alcohol (3.28\%). In addition, this is the first report made on the composition of bark from $B$. cruckshanksii in which terpenes were the predominant portion.

\section{Cytotoxic activity}

The cytotoxic activity of $B$. cruckshanksii extracts was evaluated using a colorimetric assay, in vitro against three different cancer cell lines and two nontumour cell line of human cells. The half-maximal inhibitory concentration $\left(\mathrm{IC}_{50}\right)$ values of the most active extract and their respective fractions are summarized in Table No. 3. The $\mathrm{IC}_{50}$ values of the remaining extracts they were not shown because they were not significantly active.

Table No. 3

Cytotoxic activity of the bark ethyl acetate extract and fractions from B. cruckshanksii.

\begin{tabular}{|c|c|c|c|c|c|c|c|c|c|c|}
\hline \multirow[b]{2}{*}{ Cell } & \multicolumn{10}{|c|}{$\mathrm{IC}_{50}(\mu \mathrm{g} / \mathrm{mL})$} \\
\hline & Crude* & F1 & F2 & F3 & F4 & F5 & F6 & F7 & Dau $^{\mathbf{a}}$ & Dox $^{b}$ \\
\hline MCF-7 & $12.4 \pm 0.12$ & $>50.0$ & $44.2 \pm 0.3$ & $>50.0$ & $18.6 \pm 0.4$ & $48.2 \pm 0.5$ & $>50.0$ & $>50.0$ & $0.89 \pm 0.21$ & $1.19 \pm 0.51$ \\
\hline HT-29 & $10.0 \pm 0.01$ & $>50.0$ & $39.5 \pm 0.1$ & $>50.0$ & $13.9 \pm 0.1$ & $37.2 \pm 0.1$ & $>50.0$ & $>50.0$ & $14.9 \pm 0.3$ & $0.69 \pm 0.33$ \\
\hline PC-3 & $9.8 \pm 0.11$ & $>50.0$ & $38.4 \pm 0.3$ & $41.9 \pm 0.2$ & $7.4 \pm 0.1$ & $38.7 \pm 0.3$ & $>50.0$ & $>50.0$ & $2.75 \pm 0.20$ & $2.78 \pm 0.11$ \\
\hline CON & $>50.0$ & $>50.0$ & $>50.0$ & $>50.0$ & $>50.0$ & $>50.0$ & $>50.0$ & $>50.0$ & $5.5 \pm 0.30$ & $5.61 \pm 0.31$ \\
\hline HDF & $>50.0$ & $>50.0$ & $>50.0$ & $>50.0$ & $>50.0$ & $>50.0$ & $>50.0$ & $>50.0$ & $14.5 \pm 0.11$ & $10.3 \pm 0.23$ \\
\hline
\end{tabular}

*Crude: bark ethyl acetate extract; ${ }^{\text {a }}$ : Daunorubicin; ${ }^{\text {b }}$ Doxorubicin

Among the extracts tested, the results revealed that the ethyl acetate extract and fraction F4 showed the highest cytotoxic activity against all cancer cell lines, without affecting non-tumoral cells. However, due to the activity shown by the F4, it was subjected to GC-MS to identify the components in the fraction responsible for the cytotoxic activity observed in the study. Aromadendrene and patchouli alcohol (PA) were the main compounds in the fraction; these terpenes are found in many essential oils, and these compounds show a wide spectrum of action involving antitumor, antiviral, antibacterial and cytotoxic activity (Oliveira et al., 2015; Pavithra et al., 2018). In addition, PA exert an anti-cancer activity via a decrease of cell growth and an increase of apoptosis in human cancer cells (Jeong et al., 2013). Moreover, syringaldehyde has been described for the treatment of cancer from a palliative point of view as a preventive one, due to its mass presence of fruits, vegetables and cereals of mass consumption (Colaric et al., 2005). Furthermore, there is quercetin in the fraction, which is an important member of flavonoids and is considered as attractive candidate for cancer treatment and prevention (Srivastava et al., 2016). It has also quercetin has been studied extensively as a chemoprevention agent in several cancer models (Jeong et al., 2009). On the other hand, curcumenone isolated from the rhizomes of Curcuma zedoaria has been reported to induce apoptosis in MCF-7 cells by inhibiting the proliferation of the cancer cells (Ahmed-Hamdi et al., 2014). In addition, the presence in the extract of methyleugenol (ME) is a substituted alkenylbenzene found in a variety of foods, products, and essential oils, and ME is a potent anticancer agent in RB355 human retinoblastoma cells (Ahmed-Hamdi et al., 2014), justifies the potential antiproliferative activity of this extract or fraction on different cancer cell lines. Interestingly, F4 presented a cytotoxicity close to the postitive controls used in the study, with an activity superior to daunorubicin in HT-29, see Table No. 2.

\section{CONCLUSIONS}

The ethyl acetate extract from the bark of $B$. cruckshanksii exhibited promising anticancer activity and is therefore and can be a potential source of molecules to be exploited in medicine or by the pharmaceutical industry for the fight against cancer.

\section{ACKNOWLEDGMENTS}

The authors thank the Dirección General de Investigación of Universidad de Playa Ancha for Concurso Interno Financiamiento de Tesis 2018 and Programa de Biodiversidad Facultad de Ciencias Naturales y Exactas, 2016-2017. This research was funded by FONDECYT (Grant No. 11140193). 


\section{REFERENCES}

Ahmed-Hamdi O, Syed-Abdul-Rahman S, Awang K, Abdul-Wahab N, Looi C, Thomas N, Abd-Malek S. 2014. Cytotoxic constituents from the rhizomes of Curcuma zedoaria. Sci World J 2014: 321943. https://doi.org/10.1155/2014/321943

Canales N, Montenegro I, Párraga M, Olguín Y, Godoy P, Werner E, Madrid A. 2016. In vitro antimicrobial activity of Embothrium coccineum used as traditional medicine in Patagonia against multiresistant bacteria. Molecules 21:1441. https://doi.org/10.3390/molecules21111441

Colaric M, Veberic R, Solar A, Hudina M, Stampar F. 2005. Phenolic acids, syringaldehyde, and juglone in fruits of different cultivars of Juglans regia L. J Agr Food Chem 53: 6390 - 6396. https://doi.org/10.1021/jf050721n

Elufioye TO, Abdul AA, Moody JO. 2017. Cytotoxicity studies of the extracts, fractions, and isolated compound of Pseudocedrela kotschyi on cervical cancer (HeLa), breast cancer (MCF-7) and skeletal muscle cancer (RD) cells. Pharmacogn Res 9: 46 - 50. https://doi.org/10.4103/0974-8490.199776

Furtado FB, Borges BC, Teixeira TL, Garces HG, Almeida Junior LD, Alves FCB, Silva CV, Fernandes Junior A. 2018. Chemical composition and bioactivity of essential oil from Blepharocalyx salicifolius. Int J Mol Sci 19: 33. https://doi.org/10.3390/ijms19010033

Gusinde M. 1936. Plantas medicinales que los indios Araucanos recomiendan. Anthropos 31: 850 - 873.

Jeong JH, An JY, Kwon YT, Rhee JG, Lee YJ. 2009. Effects of low dose quercetin: cancer cell-specific inhibition of cell cycle progression. J Cell Biochem 106: 73 - 82. https://doi.org/10.1002/jcb.21977

Jeong JB, Choi J, Lou Z, Jiang X, Lee SH. 2013. Patchouli alcohol, an essential oil of Pogostemon cablin, exhibits anti-tumorigenic activity in human colorectal cancer cells. Int Immunopharmacol 16: 184 - 190. https://doi.org/10.1016/j.intimp.2013.04.006

Madrid Villegas A, Espinoza Catalán L, Montenegro Venegas I, Villena García J, Carrasco Altamirano H. 2011. New catechol derivatives of safrole and their antiproliferative activity towards breast cancer cells. Molecules 16: 4632 - 4641. https://doi.org/10.3390/molecules16064632

Massardo, F.; Rozzi, R. 1996. Valoración de la Biodiversidad: Usos medicinales de la flora nativa chilena. Ambiente y Desarrollo 12: 76 - 81.

Mbaveng AT, Damen F, Mpetga JD, Awouafack MD, Tane P, Kuete V, Efferth T. 2019. Cytotoxicity of crude extract and isolated constituents of the Dichrostachys cinerea bark towards multifactorial drug-resistant cancer cells. Evi Based Complement Alt Med 2019: 8450158. https://doi.org/10.1155/2019/8450158

Mellado M, Soto M, Madrid A, Montenegro I, Jara-Gutiérrez C, Villena J, Werner E, Godoy P, Aguilar LF. 2019. In vitro antioxidant and antiproliferative effect of the extracts of Ephedra chilensis $\mathrm{K}$ Presl aerial parts. BMC Complement Alt Med 19: 53. https://doi.org/10.1186/s12906-019-2462-3

Nguyen VT, Scarlett CJ. 2019. Cytotoxic activity of extracts and fractions from Paramignya trimera root and Phyllanthus amarus against pancreatic cancer cell lines. J Can Res Ther 15: 245 - 249. https://doi.org/10.4103/jcrt.jcrt_85_18

Oliveira P, Alves JM, Damasceno J, Oliveira R, Dias H, Crotti A, Tavares DC. 2015. Cytotoxicity screening of essential oils in cancer cell lines. Rev Bras Farmacogn 25: 183 - 188. https://doi.org/10.1016/j.bjp.2015.02.009

Pavithra PS, Mehta A, Verma RS. 2018. Synergistic interaction of $\beta$-caryophyllene with aromadendrene oxide 2 and phytol induces apoptosis on skin epidermoid cancer cells. Phytomedicine 47: 121 - 134. https://doi.org/10.1016/j.phymed.2018.05.001

Siqueira E, Oliveira DM, Johann S, Cisalpino PS, Cota BB, Rabello A, Alves TMA, Zani CL. 2011. Bioactivity of the compounds isolated from Blepharocalyx salicifolius. Rev Bras Farmacogn 21: 645 - 651. https://doi.org/10.1590/s0102-695x2011005000111

Srivastava S, Somasagara R, Hegde M, Nishana M, Tadi SK, Srivastava M, Choudhary B, Raghavan SC. 2016. Quercetin, a natural flavonoid interacts with DNA, arrests cell cycle and causes tumor regression by activating mitochondrial pathway of apoptosis. Sci Rep 6: 24049. https://doi.org/10.1038/srep24049 
Tantengco OA, Jacinto SD. 2015. Cytotoxic activity of crude extracts and fractions from Premna odorata (Blanco), Artocarpus camansi (Blanco) and Gliricidia sepium (Jacq.) against selected human cancer cell lines. Asian Pac J Trop Biomed 5: 1037 - 1041. https://doi.org/10.1016/j.apjtb.2015.09.011

WHO. 2019 (World Health Organization). https://www.who.int/news-room/fact-sheets/detail/cancer 